\title{
From demographic dividend to demographic burden: the impact of population ageing on economic growth in Europe
}

\author{
Paper submitted for publication in TESG
}

Final draft: 31 January 2014

\author{
Nicole van der Gaag • Joop de Beer \\ Netherlands Interdisciplinary Demographic Institute (NIDI-KNAW), University of Groningen, P.O. Box 11650, \\ 2502 AR The Hague, The Netherlands \\ Telephone: +31 7035652 00; telefax: +31 70364 71 87; e-mail: gaag@nidi.nl; beer@nidi.nl \\ Corresponding author: Nicole van der Gaag
}

\begin{abstract}
In the coming years, the share of the working-age population in the total population will start to decline in all countries of the European Union. All other things remaining equal, this so-called demographic burden will have a downward effect on economic growth. This paper examines whether the Europe 2020 employment targets would be sufficient to compensate for the downward impact of demographic burden and whether the impact of demography on economic growth differs between EU countries and between urban and rural regions. The results show that raising employment rates to the Europe 2020 targets can restore positive opportunities for economic growth, but not in all countries and only to a limited extent. They also show that even though urban and rural regions differ in terms of population growth and growth of the working age population, the prospects for demographic burden are highly similar for both types of regions.
\end{abstract}

Keywords: demographic dividend, demographic burden, economic growth, population ageing, European regions

\section{INTRODUCTION}

Although research on the impact of population growth on economic growth did not produce a univocal conclusion (a.o. Easterlin, 1967; Blanchet, 1991; Bucci, 2008), more recently several studies showed that demography matters once you take into account the age structure of the population (Bloom et al., 2003; Prskawetz et al., 2007). Populations with high proportions of children and elderly tend to spend more of their income to care for the young and the old, which may depress economic growth, while populations with increasing proportions of the working-age population may profit from the corresponding increase in labour supply. In periods with rising proportions of the population in their productive ages, their contribution to economic growth can be regarded as demographic dividend (Bloom et al., 2003). Based on an extensive meta-analysis of macro-economic literature, Headey and Hodge (2009) showed that growing working-age populations have a positive effect on economic growth. 
Generally, there are two different ways in which demographic dividend may add to economic growth (Prskawetz et al., 2007). First through labour supply. This is called the accounting effect and refers to the relative increase of the numbers of workers compared to the number of dependent persons. Increasing labour supply, however, will not automatically lead to increasing levels of economic growth. Without a proper functioning labour market, the additional labour supply may end up unemployed. In addition to the accounting effect, demographic dividend can contribute to economic growth through savings, human capital formation and technological innovation. This is called the behavioural effect and refers to opportunities to increase productivity. If more people work, personal savings may grow which can be used for industrial investments. Furthermore, if relatively less resources are needed to take care for the young and the old, more can be spent on education and to better qualify the workforce. Again good policies are needed to take full advantage of this demographic dividend. Without such policies instead of reinforcing economic growth demographic dividend may worsen it.

The main cause of demographic dividend is declining fertility and the subsequent change in the age structure of a population. The window of opportunity for benefitting from the gains of demographic dividend is limited due to population ageing. Once the growth rate of the working-age population will be slower than the growth rate of the total population, the share of the working-age population will start to decline and demographic dividend will turn into demographic burden. In this case an increasing share of the population depends on the output produced by a decreasing share of the working-age population. All other things remaining equal, demographic burden results in declining economic growth. While demographic dividend still may offer opportunities for economic growth to many countries in the developing world, for most European populations this demographic dividend is almost spent as the share of the working-age population will soon start to decline.

Labour input to economic growth is not only determined by the size of the working-age population but also depends on labour market participation, i.e. the proportion of the working-age population actually employed and the average number of hours worked per employee. To anticipate demographic burden, increasing employment rates is a central theme in many labour market policies in European countries, and is one of the headline targets of the Europe 2020 strategy for smart, sustainable and inclusive growth (CEC, 2008a). Labour market policies to boost employment may for instance include measures to increase labour force participation of the youth and reduce youth unemployment, to enhance employability of specific groups such as women, migrants and people with disabilities, and to raise retirement age and promote active ageing. Often these measures are complemented by tax reforms. As development opportunities of different regions may vary, to achieve the objectives of the Europe 2020 Strategy the territorial dimension of the strategy has to be taken into account. Territorial cohesion, therefore, is another objective of the Europe 2020 strategy (CEC, 2008b). Implicit to the notion of 
territorial cohesion is a more balanced and sustainable development. As the risk of social exclusion is higher in areas with weak economic performance, regional differences in the prospects of ageing and demographic burden may have severe impacts on social and territorial cohesion.

In this paper we discuss recent and future developments in the contribution of labour input to economic growth in the European Union in the period 2000-2020. Point of departure is the prospect of a declining working-age population (Lanzieri, 2011; European Union, 2012). The main objective is to study the impact of population ageing on labour input and to examine to what extent employment rates should raise in order to compensate for demographic burden, and whether the Europe 2020 employment targets are sufficient to reach these levels. We also pay attention to the question whether demographic burden differs between urban and rural regions, and if so, whether this will support or threaten territorial cohesion.

The organization of this paper is as follows. In the next section, we pay attention to the relationship between demography and economic growth. We shortly discuss the theoretical background and describe for a number of countries of the European Union the contributions to economic growth of the working-age population, labour market participation, and labour productivity. Then we zoom in on demographic developments between 2000 and 2020 and show that demographic dividend will turn into demographic burden for all countries of the EU27. In the following section we turn to the possible impact of employment gains. Subsequently, we pay attention to differences in demographic developments between urban and rural regions at NUTS 2 level. The final section reflects on the main conclusions.

\section{DEMOGRAPHY AND ECONOMIC GROWTH}

Many different factors play a role in the relationship between demography and economic growth, and various indicators may be used to measure either economic growth or the impact of demography on economic growth. Often, economic growth is measured as the annual percentage change in gross domestic product (GDP), either in total volume or per capita of the population. While the total volume of GDP refers to a country's overall output of goods and services at market prices, GDP per capita is especially useful for making cross country comparisons as well as for making comparisons over time. Using GDP as a measure of economic growth has a number of drawbacks. For instance, it does not include unpaid work and it only takes into account productivity but not the quality of the output produced nor the quality of life of those who produce the output, and it ignores values like social cohesion and the environment (Lequiller, 2004). Other measures of economic development include for instance a high occupancy or low vacancy rate for existing office, retail, and industrial buildings, job 
retention and creation, job-to-resident ratios, or new businesses and business start-ups (Ammons and Morgan, 2011). For a comprehensive overview of the economic situation in a specific country the use of a combination of several of these indicators would be preferred over the sole use of GDP. For general purposes and making comparisons across countries, however, despite its shortcomings, GDP is a widely used indicator of a country’s overall economic performance.

To identify the contribution of demography, labour market participation and productivity to GDP, we decompose GDP into different components in a similar way as Denton and Spencer (1997):

GDP $=$ Pop * WAP/Pop * workers/WAP * hours/workers * GDP/hours

where

GDP $=$ Gross Domestic Product

Pop $=$ Total population

WAP $=$ Working-age population defined as population aged 20-64

workers $=$ Total number of persons in the work force

hours $=$ Total number of hours worked

The first two components of this identity refer to the contribution of demography: the total population of a country (Pop) and the share of the working-age population in the total population (WAP/Pop). Together they form the working-age population (WAP). The third and the fourth components refer to the contribution of labour market participation: the employment rate (workers/WAP) and working hours per employee (hours/workers). These four components make up the labour input to GDP and refer to the total number of hours worked by all workers together. The last component, output per labour hour (GDP/hours) refers to productivity or the efficiency of the workforce.

Based on data from Eurostat ${ }^{1}$ and the $\mathrm{OECD}^{2}$ we calculated the contributions to GDP of the different components for all countries of the European Union for which all data were available and with a population of at least 4 million inhabitants. Table 1 presents GDP and GDP per capita for 2010 and the values of the different components contributing to GDP. Productivity is calculated as the residual of the other components. This table shows broadly three different groups. First, Italy and Spain with levels of GDP per capita around the EU value. Typical of these countries is their relatively low employment rate. The second group of countries consists of the central and eastern European countries, together with Greece and Portugal. These countries show below average GDP per capita

\footnotetext{
${ }^{1}$ Eurostat database available at http://epp.eurostat.ec.europa.eu/portal/page/portal/statistics/search database; data from population and social conditions (population data and employment rates), economy and finance (GDP), and general and regional statistics (regional level population data).

${ }^{2}$ OECD data on average annual hours actually worked per worker available at http://stats.oecd.org/Index.aspx?DatasetCode=ANHRS
} 
mainly due to low productivity (all below average), in some cases together with relatively low employment rates. The high numbers of working hours in Greece, Hungary and Poland, could not change this unfavourable position. The remaining countries show above average GDP per capita mainly because of high levels of efficiency. What strikes most is the relatively high employment rate, low numbers of hours worked and high productivity in the Netherlands, resulting in the highest level of GDP per capita in 2010 in the countries involved.

Table 1 about here

If we look at the contribution of the different components of labour input to the annual average percentage change in GDP in the period 2000-2010 (Figure 1), we see for most countries a positive contribution of the total population and changes in the employment rates. Rising employment rates may either come from declining unemployment or from increasing participation. In several central and eastern European countries and in Spain and Ireland, also growing shares of the working-age population contributed to GDP growth. Decreasing numbers of working hours on the other hand, negatively influenced GDP growth in all countries, but Belgium.

Figure 1 about here

In the past decade, in most countries GDP growth as a result of changes in the labour input came from demographic change. Even though in several countries employment rates increased, in more than half of these countries this increase was not sufficient to compensate for the lower average number of hours worked per employee. Only six countries, Belgium, Germany, Italy, Poland, Slovakia and Sweden, experienced annual average growth due to labour market participation, with annual average growth levels varying from 0.01 per cent per year in Sweden to 0.40 per cent per year in Germany. With the exception of Ireland, in the other countries the change varied from -0.04 per cent on average per year in Spain to -0.70 in Portugal. In Ireland, significant declines in both the number of hours (from 1719 to 1542 ) as well as the employment rate (from 0,70 to 0,65 ) took place, corresponding to an average annual decrease of -1.93 per cent.

Looking at the contribution of demography to labour input, in the majority of the countries we see positive change for both the total population as well as the share of the working-age population. Only in Germany the population in 2010 counted fewer people than in 2000 and the share of the workingage population declined, resulting in an average annual decline in labour input of -0.34 per cent. This decline, however, was less numerous than the increase in labour input due to labour market participation, thus in total, labour input in Germany slightly grew. Hungary is the only other country with a negative contribution of demography to labour input, but the decline is very modest $(-0.01$ per cent). 


\section{FROM DEMOGRAPHIC DIVIDEND TO DEMOGRAPHIC BURDEN}

In 2012, the total number of inhabitants in the European Union was slightly over 500 million (source: Eurostat). Since the start of this century the annual average growth rate has been below 0.5 per cent per year, which is similar to other developed countries but modest in comparison to other world regions. While the majority of the countries in the European Union saw their population grow in the past decade, the population of most of the Eastern European countries, Hungary and also Germany started to decline (Figure 2, left graph, dark bars). With an average annual population decline of 0.8 per cent, the drop was most severe in Bulgaria.

Figure 2 about here

According to the latest Eurostat population scenarios (EUROPOP2010, Lanzieri, 2011) by 2020 in most EU countries the total population is expected to outnumber the current population (Figure 2, left graph, white bars). A different pattern applies to the working-age population. While most countries saw their working-age population still grow in the past ten years (Figure 2, right graph, dark bars), in the coming years most countries will have to face a declining working-age population (Figure 2, right graph, white bars). A still larger working-age population is only foreseen for Austria, Belgium, Cyprus, Italy, Luxembourg, Spain, Sweden and the United Kingdom. However, also in these countries, the growth rate of the working-age population will become smaller than the growth rate of the total population. While from 2000 to 2010, in most countries increasing shares resulted in demographic dividend, varying from 0.03 per cent per year in Austria to 0.87 per cent per year in Poland (Figure 3, dark bars), in the years to come, the share of the working-age population in the total population will start to decline in all member states. In all EU27 countries, therefore, demographic dividend will turn into demographic burden, varying from on average less than -0.1 per cent per year in Austria, Lithuania and Luxembourg to more than -0.7 per cent per year in the Czech Republic, Finland and Ireland (Figure 3, white bars). Denmark, Finland, Germany, Italy, the Netherlands and Sweden also already experienced demographic burden in 2000-2010.

Figure 3 about here

While for all countries developments in the share of the working-age population are expected to be different in 2010-2020 compared to 2000-2010, the differences are larger for central and eastern European countries than for the former EU15 countries. While in the EU15 countries the baby boom generation first brought demographic dividend, this dividend will turn into demographic burden once the baby boom generation reaches retirement age. Eastern and central European Union countries have 
no baby boom generations. In these countries, a constant fertility decline together with stagnating or even declining life expectancies since the fall of the Iron Curtain resulted in demographic dividend in the recent past, while current and expected increases in fertility and life expectancy will boost demographic burden in the years to come. Note that apart from fertility and mortality also migration plays a part. In countries or regions with high levels of fertility and high net immigration, the effect of ageing on the size of the working age population may be mitigated, whilst in countries or regions with high net emigration the effect may be reinforced. Even though the EUROPOP2010 population projections do take into account increasing levels of (labour) migration in case of declining workingage populations (Lanzieri, 2009), this is not sufficient to avoid the transition to demographic burden in the years to come.

The trend of demographic burden is expected to continue until 2060. For several decades therefore, economic growth in the EU will need to come from increasing employment rates due to increasing activity or decreasing unemployment and/or increasing numbers of hours worked per employee, or increasing productivity (output per hour worked). Different countries may have different opportunities to cope with demographic burden. In Hungary and Italy, for instance, efforts to increase employment rates may prove to be successful measures to ensure economic growth, while in the Netherlands, Germany, Denmark and Ireland, efforts to increase the numbers of hours may prove to be more effective. In countries where both employment rates and the number of hours worked are relatively high, such as in Austria, Finland, Sweden and the United Kingdom, measures to increase productivity may hold the best prospects.

\section{EMPLOYMENT GAINS}

Given the expected change in the total population and the share of the working-age population in the period 2010-2020 we raised the question how much growth in employment rates is needed to compensate declines in labour input due to demographic change. Figure 4 shows the expected annual average change in the total population (white bars) and the share of the working-age population (dotted bars), as well as the annual average change in employment rates needed to compensate for changes in the size of the working-age population ${ }^{3}$ (white circles) and demographic burden (grey circles). The sequence of the countries is according to the annual average change in employment rates needed to reach the Europe 2020 employment targets (black stripes).

\footnotetext{
${ }^{3}$ This is the total effect of demography to labour input: Pop * WAP/Pop.
} 


\section{Figure 4 about here}

In Austria, Belgium, Cyprus, Italy, Luxembourg, Spain, Sweden and the United Kingdom the expected annual average increase in total population between 2010 and 2020 outnumbers the expected average annual decline in the share of the working-age population. For these countries employment rates do not have to increase to keep the total volume of labour input at least at the level of 2010 (Figure 4, white circles below x-axis). In Denmark the advantage of an increasing total population is cancelled out by a decreasing share of the working-age population. In the remaining countries the balance turns to the other side and small to moderate annual average increases in the employment rates are needed to keep labour input at the level of 2010 (from below 0.01 per cent in France, Ireland and Slovakia up to 0.6 per cent per year in Estonia).

If we do not look at the total volume of GDP, but at GDP per capita, then the question is how much gains in employment rates are needed to compensate for demographic burden only. In this case, the impact of the total population change is not relevant. As all countries will have to face demographic burden, in all countries some gains in employment rates are needed to keep output per capita at current levels (Figure 4, grey circles). However, in countries with population decline, a smaller increase in employment rate may be sufficient to keep GDP per capita constant compared to keeping the total volume of GDP constant. This applies to Germany, Estonia and Hungary. In countries with relatively large population gains, on the other hand, like Ireland, Sweden and the United Kingdom, much larger increases in employment rates are needed.

A next question is whether the Europe 2020 employment targets will be sufficient to reach the employment gains necessary to compensate for demographic burden. The overall target for the EU is to increase employment rates to 75 per cent by 2020 through greater participation of the youth, older workers, low-skilled workers and migrants. This overall target is translated into national targets set by the member states in their national reform programmes. National target values vary from 62.9 per cent in Malta to 80 per cent in Denmark and the Netherlands, and 'well above 80 per cent' in Sweden (Table 2).

Table 2 about here

The black stripes in Figure 4 show the average annual percentage change in employment rates needed to reach the national employment targets of the Europe 2020 strategy for the period 2010-2020. In most countries, raising the employment rates to the national targets of the Europe 2020 strategy will more than compensate demographic burden, leaving room for increasing labour input to economic growth, given that the number of hours worked per employee will not decline. For the Czech Republic, Finland, Malta, and the Netherlands, reaching the employment target is not sufficient. For 
Germany, the employment target is sufficient to compensate demographic burden, but not to compensate population decline. In these five countries, therefore, also increases in numbers of hours worked or productivity are needed to avoid decline of GDP per capita (CZ, FI, NL, MT) or total GDP (Germany). As the United Kingdom did not define a national employment target in their National Reform Programme, we calculated for the UK whether the EU27 target of 75 per cent employment would be sufficient to compensate for demographic burden, which turned out not to be the case. The EU27 target, however, differs only slightly from the current employment rate in the UK and some more scope for raising employment rates in the UK seems to be available.

The average annual change needed to bridge the gap between current employment rates and the national targets for 2020 differs largely across countries. For most countries, reaching the employment target will require a much higher annual average growth in employment rates than observed on average in the period 2000-2010. Note however, that as a consequence of the economic crisis, in the period 2008-2010 employment rates dropped significantly in almost all countries (Table 2). In Estonia, Ireland and Latvia employment rates even declined more than 10 per cent. In these countries, the target for 2020 is still below the level observed in 2008. Since 2010, in slightly more than half of the countries the rates went up again, with the largest increases in the Baltic States. In about one third of the countries, however, recent developments further diverge from the employment targets. Especially in the southern countries that were hit most by the crisis the declines were significant. On the contrary, in the period 2000-2008, some countries showed large increases, up to about 8 per cent points in Spain, 10 in Estonia, 12 in Latvia and even 15 in Bulgaria. Whether such large increases can be realized in the years to come, will depend on economic developments and the way to which implementation of policy measures to raise employment rates will be successful. For Hungary, however, reaching the target requires more than 2 per cent growth per year, which seems to be very optimistic.

\section{REGIONAL DIFFERENCES}

The European territorial policy debate repeatedly discusses how demographic changes present serious challenges to territorial development (the Lisbon Strategy (CEC, 2007), the Territorial Agenda (European Commission, 2011), the Commission’s Green Paper on Territorial Cohesion (CEC, 2008b) and the Europe 2020 discussions for smart, sustainable and inclusive growth (CEC, 2008a)). The main assumption behind the EUROPOP population projections is that socio-economic and cultural differences between the member states of the European Union will fade in the very long term, resulting in converging demographic indicators. In addition, the scenarios assume that immigration will increase if the size of the working-age population decreases. The regional population scenarios 
EUROPOP2008 ${ }^{4}$ are based on the assumption that within each country regional differences in the levels of fertility, mortality and international migration at the NUTS 2 level will fall by 25 per cent by 2030, and that internal migration patterns within each country will remain the same (Giannakouris, 2010). As a considerable part of population growth in urban areas can be attributed to migration, and these migration flows have caused declining population growth or population loss in many rural regions, assuming constant internal migration patterns may imply that urban regions will suffer less from demographic burden than rural regions. Declining differences in the levels of fertility, mortality and international migration on the other hand may point in the opposite direction.

In order to map out the consequences of demographic burden for urban and rural regions as projected by the EUROPOP2008 population projections, we use the EU urban-rural classification at the NUTS 2 level developed by De Beer et al. (2012) based on the lower level classifications of Eurostat and the OECD (Eurostat, 2010, OECD, 2010). These classifications distinguish 'Predominantly Urban', 'Intermediate' and 'Predominantly Rural' areas. About half of the population in the European Union lives in predominantly urban NUTS 2 regions, slightly more than a quarter in predominantly rural regions and slightly less than a quarter in intermediate regions (De Beer et al., 2012). We examined whether demographic dividend and/or burden is different in predominantly rural compared to predominantly urban regions. We disregarded intermediate regions because these regions form a rather heterogeneous group. Within the latter group some NUTS 2 regions are classified as intermediate because all its NUTS 3 regions are classified as intermediate, while others are classified as intermediate because they contain both urban and rural NUTS 3 populations of about equal size. This may obscure the comparisons between the different types of regions. Furthermore, we took only into account countries where both the percentage of the urban and rural population was at least 20 per cent of the total population in the country. These countries are Austria (25 per cent urban, 48 per cent rural), Bulgaria (28/57 per cent), the Czech Republic (24/38 per cent), Denmark (30/70 per cent), Finland (50/50 per cent), France (48/32 per cent), Germany (51/20 per cent), Greece (36/41 per cent), Hungary (30/70 per cent), Poland (42/33 per cent), Portugal (29/34 per cent) and Sweden (22/27 per cent).

Figure 5 shows the annual average demographic dividend or burden in urban and rural NUTS 2 regions for the period 2000-2010 and the expected dividend or burden in the period 2010-2020 according to the EUROPOP2008 population scenario. Between 2000 and 2010, in several countries both urban and rural regions still experienced demographic dividend. Differences between urban and rural regions are relatively small and not systematically in favour of one of the two types of regions. The general pattern for the years to come for almost all countries for both types of regions is either the

\footnotetext{
${ }^{4}$ The latest regional population scenarios compiled by Eurostat are consistent with the EUROPOP2008 national scenarios; so far no regional EUROPOP2010 scenarios are available.
} 
transition to, or an increase in demographic burden. Only for German and Danish urban regions, a slight recovery of demographic burden is expected compared to the period 2000-2010.

\section{Figure 5 about here}

The main cause of demographic burden, or declining shares of the working-age population, is the increase in the share of the population aged 65 and over. In most countries the increase in the share of the elderly will be smaller in urban than in rural regions. As the share of the elderly in rural regions already exceeds that in urban regions, the difference in population ageing between urban and rural regions will increase further. However, in most countries the share of people under 20 will decrease more strongly in rural regions than in urban regions. This is a result of the relatively larger number of women of childbearing age in urban areas. Even though total fertility rates do not differ much between urban and rural regions, the crude birth rate (the ratio of the number of live births and the total population) in urban areas systematically outnumbers that of rural areas. The overall result is that urban regions gain population, but the increase in total population outnumbers the increase in the working-age population, while rural regions lose population with stronger declines in the working-age population compared to the total population. In both cases the share of the working-age population will drop with demographic burden as a result. Thus in terms of prospects for GDP growth, urban regions may profit from population gains while rural regions will suffer from population decline, but in terms of prospects for GDP per capita both types of regions suffer to more or less the same extent of demographic burden. Differences in demographic burden in itself, therefore, do not systematically support or threaten territorial cohesion between urban and rural NUTS 2 regions.

The main assumption behind the EUROPOP2008 regional population scenarios is convergence of demographic indicators in the long run. However, this is only one out of several possible assumptions. Even though convergence is a general basis of demographic transition theory, demographic variation remains high and is only declining slowly, and there is no conclusive evidence of convergence of the new member states to common EU levels in the short term (Coleman 2002; Lanzieri 2010). Nevertheless, common policy goals and exchange of best practices may support a framework of convergence in the long run. Assuming convergence for the short term may be less obvious. In order to study whether different scenario settings give cause to different conclusions we compared the outcomes based on the EUROPOP2008 scenarios with four other regional scenarios not only taking into account converging but also diverging patterns of demographic behaviour.

The first two alternative scenarios stress differences in population growth together with converging or diverging regional differences between NUTS 2 regions and cover the period 2005-2050. These scenarios have been developed as part of the DEMIFER project 'Demographic and migratory flows affecting European regions and cities' (De Beer et al., 2010; Rees et al., 2012). The first scenario 
stresses high population growth due to decreases in mortality, increases in fertility and large increases in migration, together with divergence of regional patterns. This so-called 'High population growth and divergence scenario' projects an overall population increase for the EU until 2050 of 20 per cent, with a more or less stable working-age population. The second scenario assumes the opposite: relatively small decreases in mortality, constant fertility patterns and declining migration levels, together with declining inequalities. This 'Low population growth and convergence scenario' projects a more or less stable EU population and a 17 per cent declining working-age population ${ }^{5}$. The other two scenarios project short-term labour market consequences of different demographic developments referring to the period 2010-2030 and describe different futures in terms of ageing and urbanization. These scenarios are compiled within the context of the NEUJOBS project 'Creating and adapting jobs in Europe in the context of a socio-ecological transition' (Huisman et al., 2012). The 'Ageing scenario’ produces a future with a strong decline in the working-age population together with a strong increase in total dependency, while the 'Urbanization scenario' describes a future with more moderate changes in terms of ageing and assumes more migrants to move to urban regions, either from abroad or from rural areas ${ }^{6}$.

A comparison of the results of the five different scenarios shows highly similar prospects: population loss in rural areas mainly due to losses in the working-age population and stable or population gains in urban areas with larger gains in total population compared to the working-age population. As could be expected, only the ageing scenario showed losses in the working-age population in urban regions. In all scenarios both urban and rural regions will have to face demographic burden and differences in demographic burden across different types of regions are only minor (Table 3). Given that different scenarios with different base years, story lines and underlying assumptions all point into the same direction, we may conclude that not only rural, but also urban NUTS 2 regions will have to face demographic burden in the coming future.

Table 3 about here

\footnotetext{
${ }^{5}$ The DEMIFER scenarios examine different futures based on alternative assumptions on economic and environmental developments and the implementation and effectiveness of regional cohesion policies. The 'High population growth and divergence scenario' corresponds to the 'Expanding Market Europe' (EME) scenario and the 'Low population growth and convergence scenario' to the 'Limited Social Europe' (LSE) scenario.

${ }^{6}$ The 'Ageing scenario' corresponds to the NEUJOBS demographic tough scenario and the 'Urbanization scenario' to the NEUJOBS demographic friendly scenario as presented during the NEUJOBS Peer Review and Validation Conference in Bratislava, 26-29 September 2012.
} 


\section{DISCUSSION AND CONCLUSION}

This paper discusses recent and future developments in the contribution of labour input to economic growth in the European Union. While in the past decade growth in GDP as a result of changes in labour input mainly came from demographic change, in the years to come all EU27 countries will see the share of the working-age population in the total population decrease, resulting in the transition from demographic dividend to demographic burden. Although in the majority of the countries the total population will continue to grow, only for a limited number of countries the expected population growth will be sufficient to compensate the negative effect of demographic burden. In most countries, raising the employment rates to the national targets of the Europe 2020 strategy can compensate this negative impact of demography, given that the number of hours worked per employee will not decline. Differences in targets, however, are huge and in some countries targets may be unrealistically high.

At the regional level, urban regions are expected to see their total and working-age populations grow until 2020, while rural regions will suffer from population decline. The share of the working-age population, on the other hand, is expected to decline to more or less the same extent in urban as in rural regions and thus differences in demographic burden do not seem to systematically support or threaten territorial cohesion between urban and rural NUTS 2 regions. Even in urban regions, therefore, the impact of demographic burden on economic growth in terms of GDP per capita, cannot easily be mitigated by migration.

The different components of GDP as given by identity (1), i.e. total population, the share of the working age population, the employment rate, the number of working hours per employee and productivity, are not necessarily independent of each other. Rising employment rates, for instance, may result in changes in the composition of the work force by age or skills, which may affect productivity (Feyrer, 2007; Prskawetz et al., 2007; The Economist, 2013). Most low employment countries in the EU tend to have a relatively low share of low-productive workers in their work force (OECD, 2009). If rising employment rates means relatively more low-productive workers entering the labour force, this will reduce productivity. Also increasing the retirement age may have a negative effect on productivity if older workers are less productive. Furthermore, rising employment rates may be related to decreasing numbers of hours worked per employee, while increasing working hours may go together with decreasing productivity.

As the impact of demographic burden will negatively affect economic growth and raising the employment rates can restore growth opportunities only to a limited extent, productivity growth will become ever more important. In the course of the 2020s, productivity growth is expected to become even the sole source for economic growth (European Union, 2012). Whether increasing productivity growth is according to expectations, however, is open to question. Van Ark et al. (2013) showed that 
across European countries, after a severe drop in productivity in 2008/09 and a rapid recovery in 2010, productivity slowed down again significantly in 2011 and 2012. For the period up to 2025 they project a decelerating productivity growth relative to the past decade.

Productivity potential may vary between urban and rural regions as economic sectors differ across regions and productivity varies by sector. In the past decades, the sectors agriculture, manufacturing, retail trade and transport experienced much more productivity gains than the sectors education, health, social work and personal services (O’Mahony et al., 2010). In general, non-market labour-intensive sectors that rely heavily on human interaction, show weak productivity growth. Therefore, the impact of demographic burden may be different for urban and rural regions, even though demographic burden itself seems not to differ too much between the two types of regions. Gáková and Dijkstra (2010) examined whether regions with a declining population are more likely to face economic decline. They showed that in the period 2000-2007 in less developed EU member states, economic growth favoured urban NUTS 3 regions, but as countries develop, and links between urban and rural regions improve, economic growth is likely to become higher in rural regions. They mention the spread of agglomeration advantages as an important reason for this more balanced growth.

Finally, different views exist on the consequences of a declining working-age population. Some people fear a shortage of labour, threatening prosperity, while others hope for the end of unemployment. Most likely, the future will be somewhere in between. In the long term labour demand may adapt to labour supply, partly by reducing unemployment (but not remove it totally) and partly by improving productivity (De Beer, 2008). In the short term, however, a transitional period may be needed to reach a new balance. Given the large variation between countries, not only in terms of demographic burden, population growth, and labour market participation, but also in terms of productivity potential, this requires tailor-made country-specific solutions. 


\section{REFERENCES}

Ammons, D. and J. Morgan (2011) State-of-the-Art Measures in Economic Development. ICMA Publications, 93:5

Blanchet, D. (1991) On Interpreting Observed Relationships Between Population Growth and Economic Growth : A Graphical Exposition. Population and Development Review 17, no. 1:105114. Retrieved from http://www.jstor.org/stable/1972354

Bloom, D.E., D. Canning, and J. Sevilla (2003) The demographic dividend, a new perspective on the economic consequences of population change. Population matters, a RAND Program of Policy Relevant Research Communication

Bucci, A. (2008) Population growth in a model of economic growth with human capital accumulation and horizontal R\&D. Journal of Macroeconomics 30: 1124-1147. doi:10.1016/j.jmacro.2007.07.011 Retrieved from http://linkinghub.elsevier.com/retrieve/pii/S0164070407001048

CEC (2007) Strategic report on the renewed Lisbon strategy for growth and jobs: launching the new cycle (2008-2010) - keeping up the pace of change. COM 2007803 final. Brussels: Commission of the European Communities

CEC (2008a) Regions 2020 - An Assessment of Future Challenges for EU Regions. Brussels: Commission of the European Communities.

CEC (2008b) Green Paper on Territorial Cohesion - Turning territorial diversity into strength. Brussels: Commission of the European Communities

Coleman, D.A. (2002) Populations of the industrial world - a convergent demographic community? International Journal of Population Geography, 8: 319-344

De Beer, P. (2008) Krimpende arbeidsmarkt: nieuw perspectief, oude problemen ('Declining labour market: new perspective, old problems'). B en M Tijdschrift voor Beleid, Politiek en Maatschappij, 2008: 35(4), pp 278-288

De Beer, J., Van der Erf, R., and Huisman, C. (2012) The growth of the working-age population: differences between rural and urban regions across Europe. NEUJOBS Working Paper D 8.1.

De Beer, J., Van der Gaag, N., Van der Erf, R., Bauer, R., Fassmann, H., Kupiszewska, D., Kupiszewski, M., Rees, P., Boden, P., Dennett, A., Jasińska, M., Stillwell, J., Wohland, P., De Jong, A., Ter Veer, A. Roto, J., Van Well, L., Heins, F., Bonifazi, C., \& Gesano, G. (2010) Final Report DEMIFER Demographic and migratory flows affecting European regions and cities. The ESPON 2013 Programme, Applied Research Project 2013/1/3

Denton, F. and B.G. Spencer (1997) Population, labour force, and long-term economic growth. IESOP Research Paper No. 25

Easterlin, R. A. (1967) Effects of Population Growth on the Economic Development of 18 Developing Countries. Annals of the American Academy of Political and Social Science 369:98-108. Retrieved from http://www.jstor.org/stable/1038476

Economist (2013) Age shall weary them, the productive challenge of the rich world's economy. The Economist, 11 May 2013

European Commission (2011) Territorial Agenda of the European Union 2020 - Towards an Inclusive, Smart and Sustainable Europe of Diverse Regions agreed at the Informal Ministerial Meeting of Ministers responsible for Spatial Planning and Territorial Development on 19th May 2011 Gödöllö, Hungary

European Union (2012) The 2012 Ageing Report, Economic and Budgetary projections for the 27 EU Member States (2010-2060). European Economy Series 2/2012

Eurostat (2010) A revised urban-rural typology. Eurostat Regional Yearbook 2010. Luxembourg: Publications Office of the European Union. http://epp.eurostat.ec.europa.eu/cache/ITY OFFPUB/KS-HA-10-001-15/EN/KS-HA-10-001-15-EN.PDF

Feyrer, J. (2007) Demographics and Productivity. The Review of Economics and Statistics, 89:100109

Gáková, Z. and L. Dijkstra (2010) Does population decline lead to economic decline in EU rural regions? Paper presented at the European Population Conference 2010, 1-4 Sept. Vienna, Austria 
Giannakouris, K. (2010) Regional population projections EUROPOP2008: Most EU regions face older population profile in 2030. Statistics in Focus, 1/2010. Luxembourg: Publications Office of the European Union

Headey, D.D. and A. Hodge (2009) The Effect of Population Growth on Economic Growth: A MetaRegression Analysis of the Macroeconomic Literature. Population and Development Review 35 (2), 221-248

Huisman, C., J. de Beer, R. van der Erf, N. van der Gaag, D. Kupiszewska (2012) Demographic scenarios 2010-2030. Paper presented at the NEUJOBS Peer Review and Validation Conference, 26-29 September 2012, Bratislava

Lanzieri, G. (2009). EUROPOP2008: A set of population projections for the European Union. Paper presented at the XXVI IUSSP International Population Conference, Marrakech, 27 Sept -2 Oct 2009.

Lanzieri, G. (2010) Is there a fertility convergence across the Member States of the European Union? Joint Eurostat/UNECE Work Session on Demographic Projections (28-30 April 2010, Lisbon, Portugal)

Lanzieri, G. (2011) The greying of the baby boomers, a century-long view of ageing in European populations Statistics in Focus, 23/2011. Luxembourg: Publications Office of the European Union.

Lequiller, F. (2004) Is GDP a satisfactory measure of growth? OECD Observer, No 246-247, December 2004-January 2005

OECD (2009) Going for Growth 2009. OECD Economic Policy Reforms. http://www.oecd.org/eco/growth/goingforgrowth.htm

OECD (2010) OECD Regional typology. OECD Directorate for Public Governance and Territorial Development. http://www.oecd.org/dataoecd/35/62/42392595.pdf

O’Mahony, M., A. Rincón-Aznar, and C. Robinson (2010) Productivity growth in Europe and the US: a sectoral study. Review of Economics and Institutions, 1 (1), Article 5. Doi:10.5202/rei.v1 I 1.5 Retrieved from http://www.rei.unipg.it/rei/article/view/5

Prskawetz, A., T. Fent, W. Barthel, J. Crespo-Cuaresma, T. Lindh, B. Malmberg, M. Halvarsson (2007) The Relationship between Demographic Change and Economic Growth in the EU, Report for Tender VT/2005/035

Rees, P., N. van der Gaag, J. de Beer and F. Heins (2012) European Regional Populations: Current Trends, Future Pathways and Policy Options. European Journal of Population - Revue Européenne de Population, 28(4), 385-416

Van Ark, B., V. Chen and K. Jäger (2013) European Productivity Growth since 2000 and Future Prospects. International Productivity Monitor, 25, 65-83

\section{ACKNOWLEDGEMENTS}

This paper has been written in the context of the NEUJOBS project 'Creating and adapting jobs in Europe in the context of a socio-ecological transition' funded by the European Commission in the context of the Seventh Framework Programme (Grant agreement no: 266833; www.neujobs.eu). We gratefully acknowledge the constructive comments of three anonymous reviewers. 
Figure 1 Annual average change in components of labour input to GDP, 2000-2010

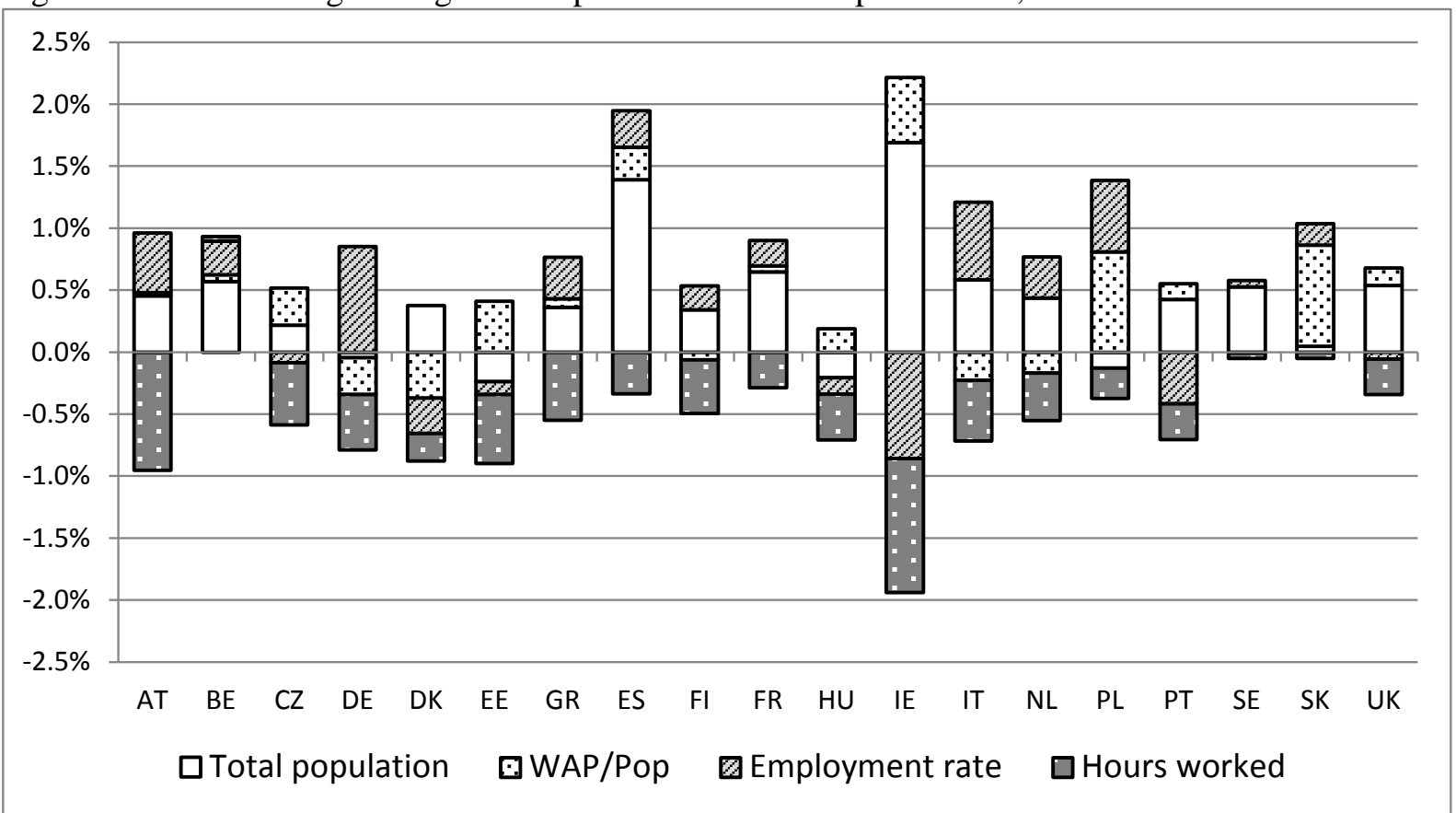

Data: Eurostat / OECD; calculations: NIDI

$\mathrm{WAP} / \mathrm{Pop}=$ share of working-age population in total population 
Figure 2 Annual average population change

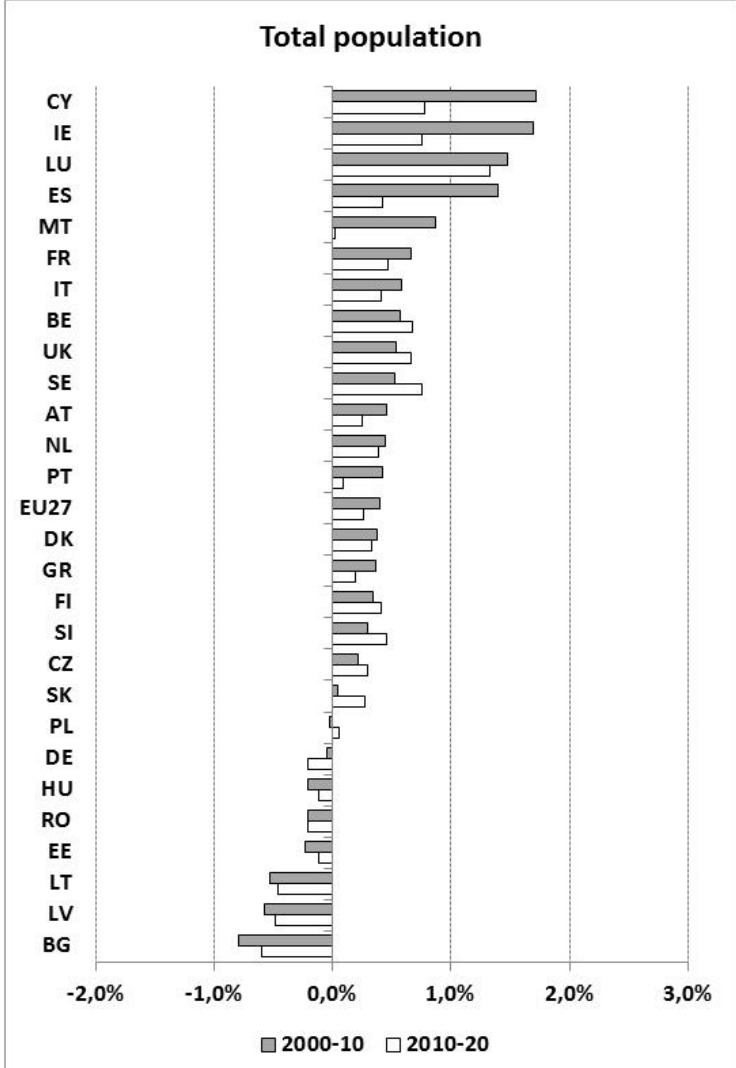

Data: Eurostat / EUROPOP2010; calculations NIDI

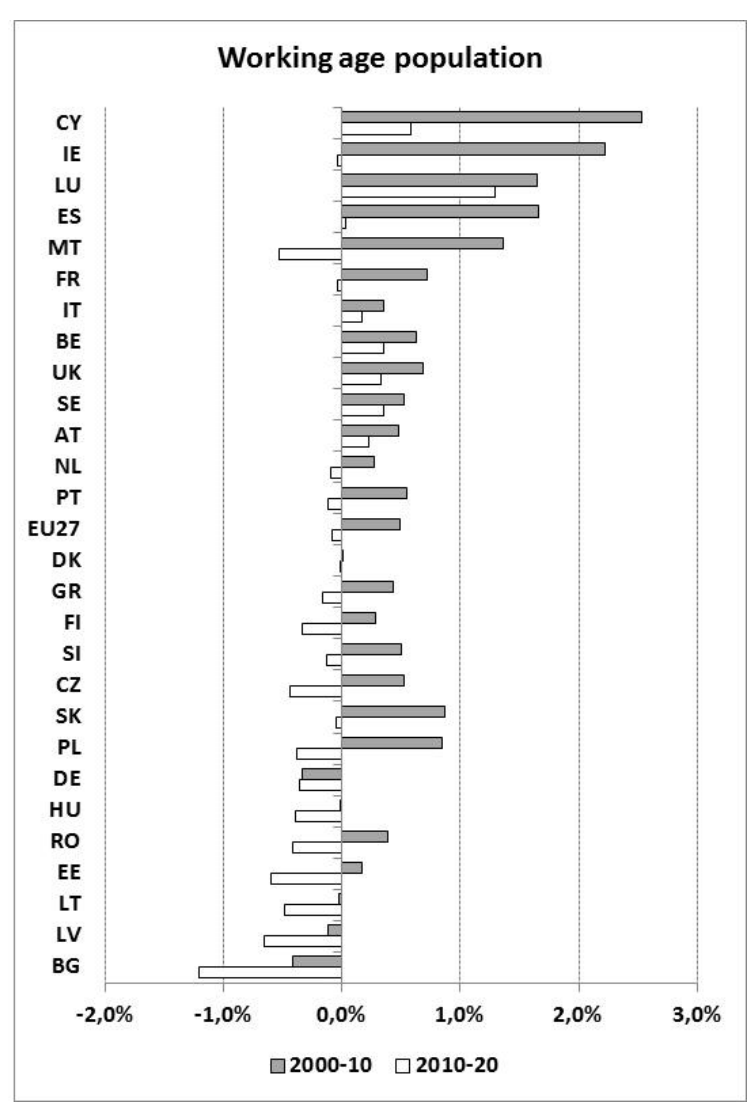


Figure 3 Annual average change in the share of the working-age population

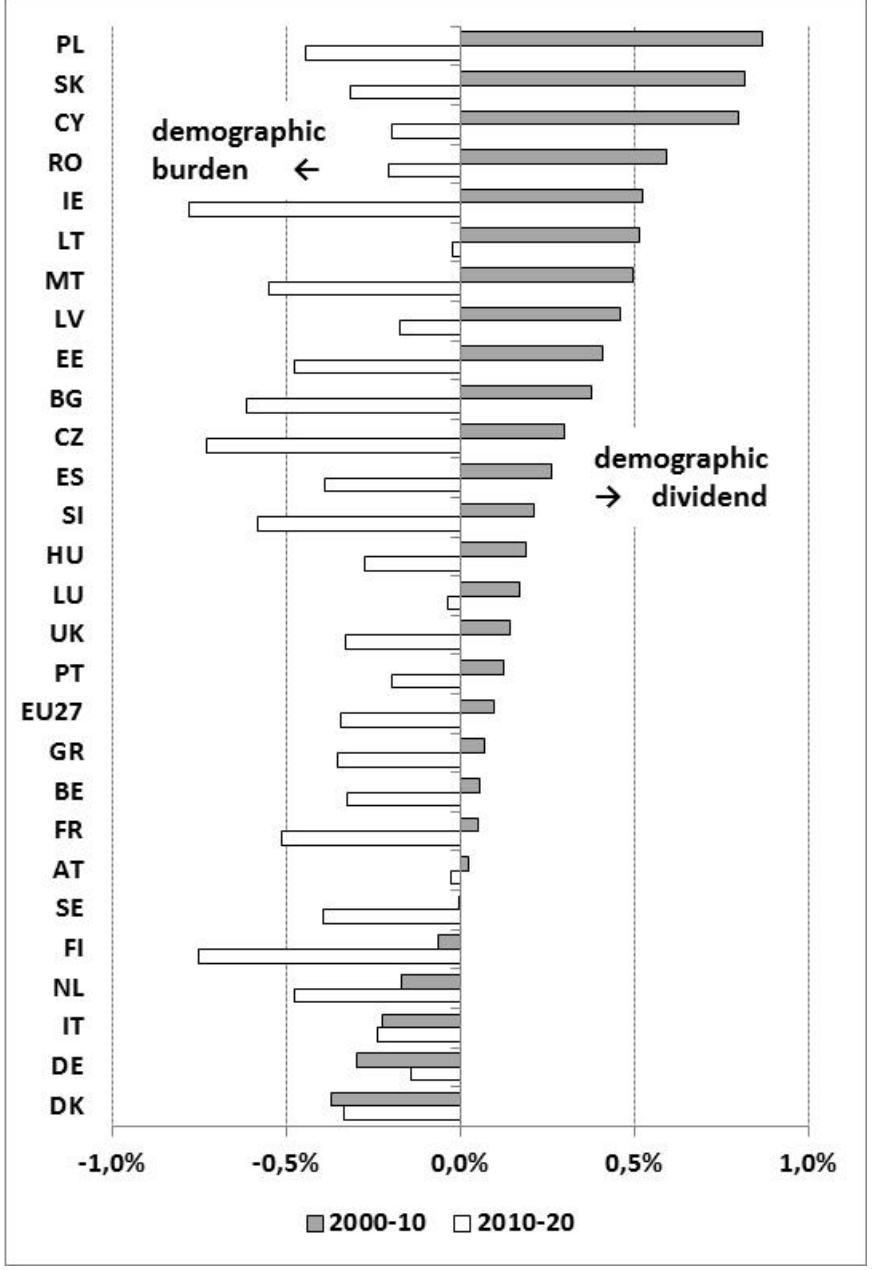

Data: Eurostat / EUROPOP2010; calculations NIDI 
Figure 4 Annual average change in employment rates to compensate for demographic developments, 2010-2020

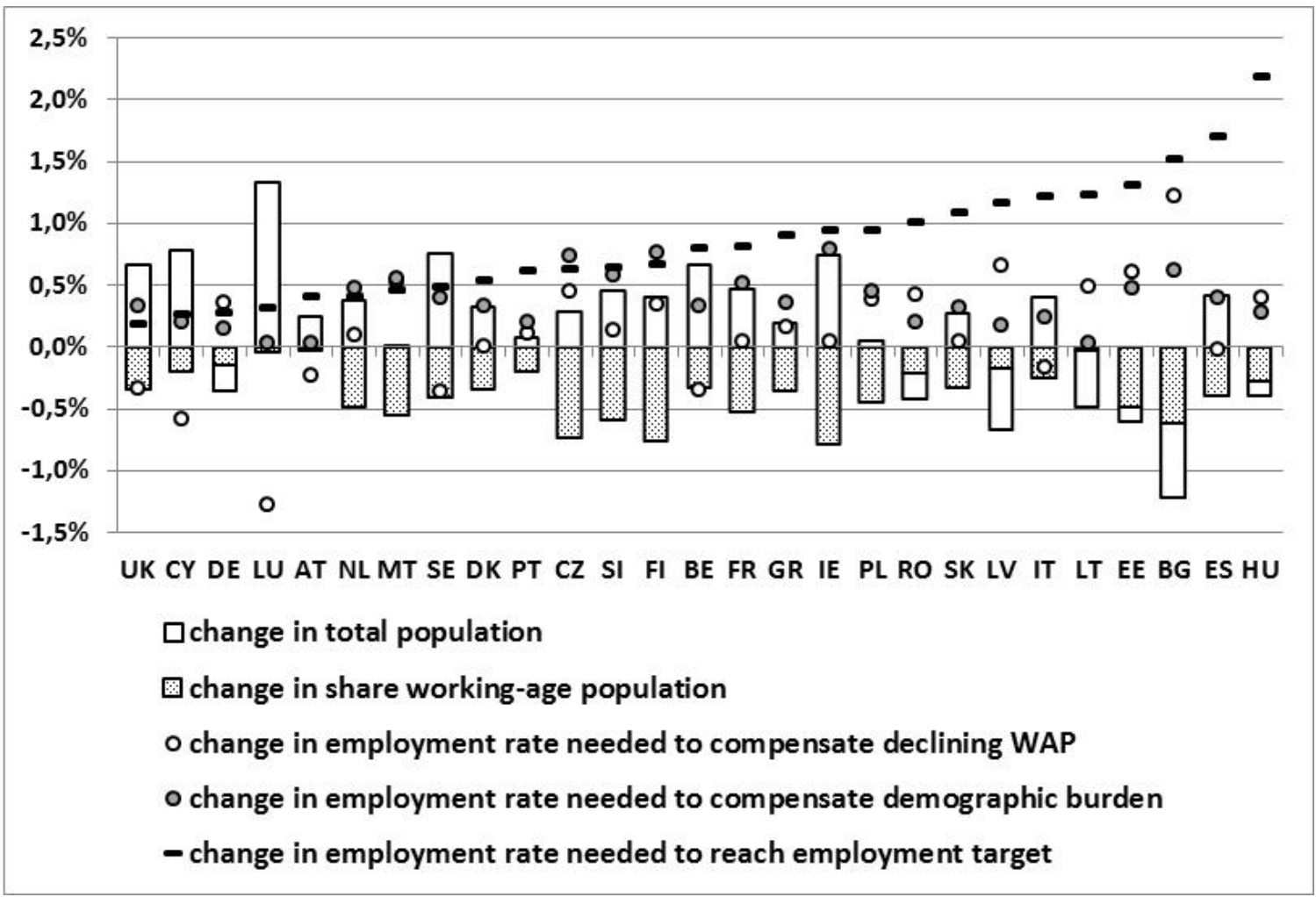

Data: Eurostat / EUROPOP2010; calculations NIDI

For Sweden and United Kingdom, employment targets are set by the authors to 82 and 75, respectively WAP: working-age population

This figure shows the expected annual average change in the total population (white bars) and the share of the working-age population (dotted bars), as well as the annual average change in employment rates needed to 1) compensate for changes in the size of the working-age population (i.e. change in total population $\mathrm{x}$ change in share working-age population; white circles), 2) compensate for demographic burden (i.e. change in share working-age population; grey circles), or 3) reach the Europe 2020 employment targets (black stripes) 
Figure 5 Annual average change in the share of the working-age population in urban and rural NUTS 2 regions

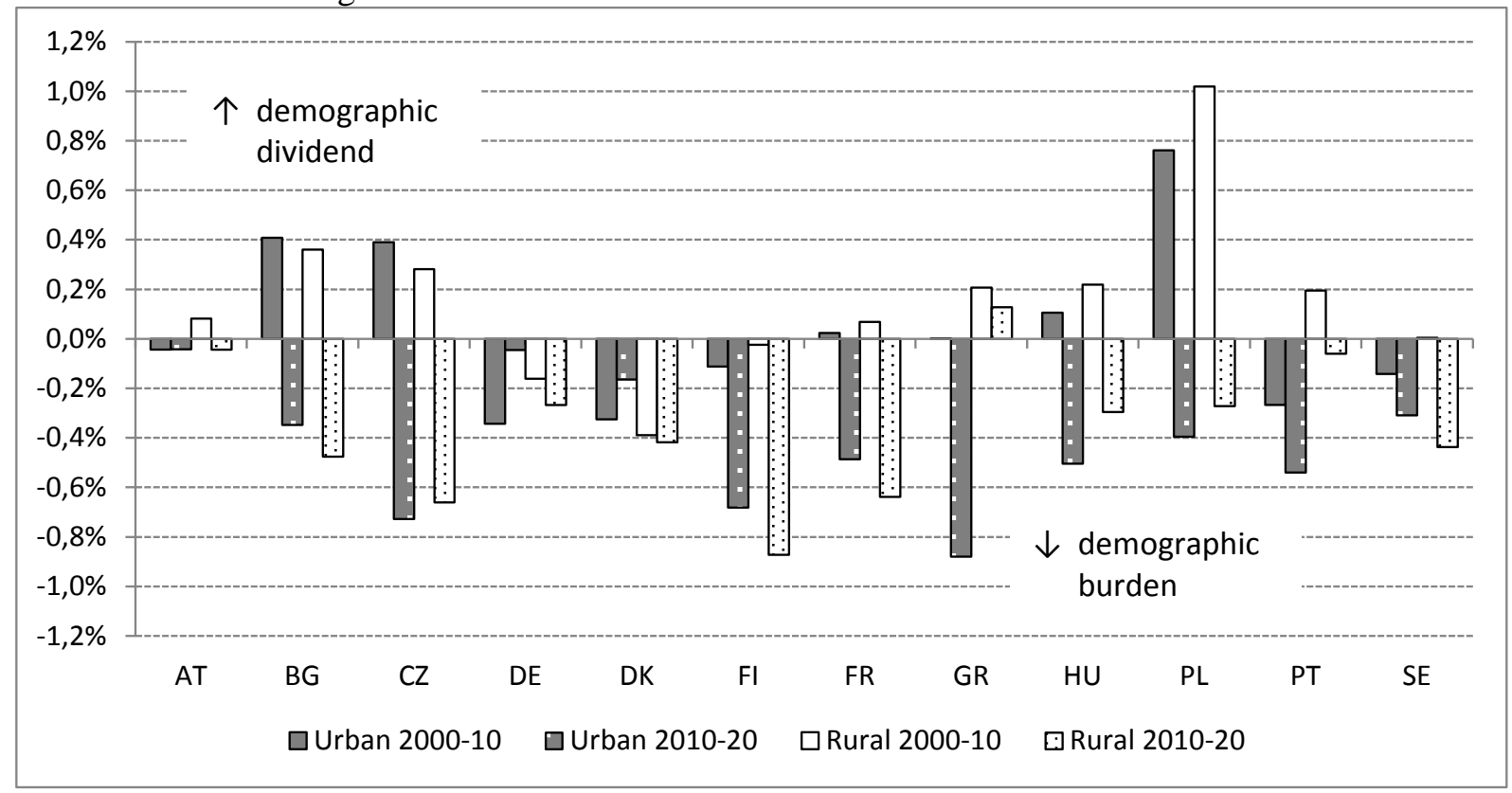

Data: Eurostat / EUROPOP2008; calculations NIDI 


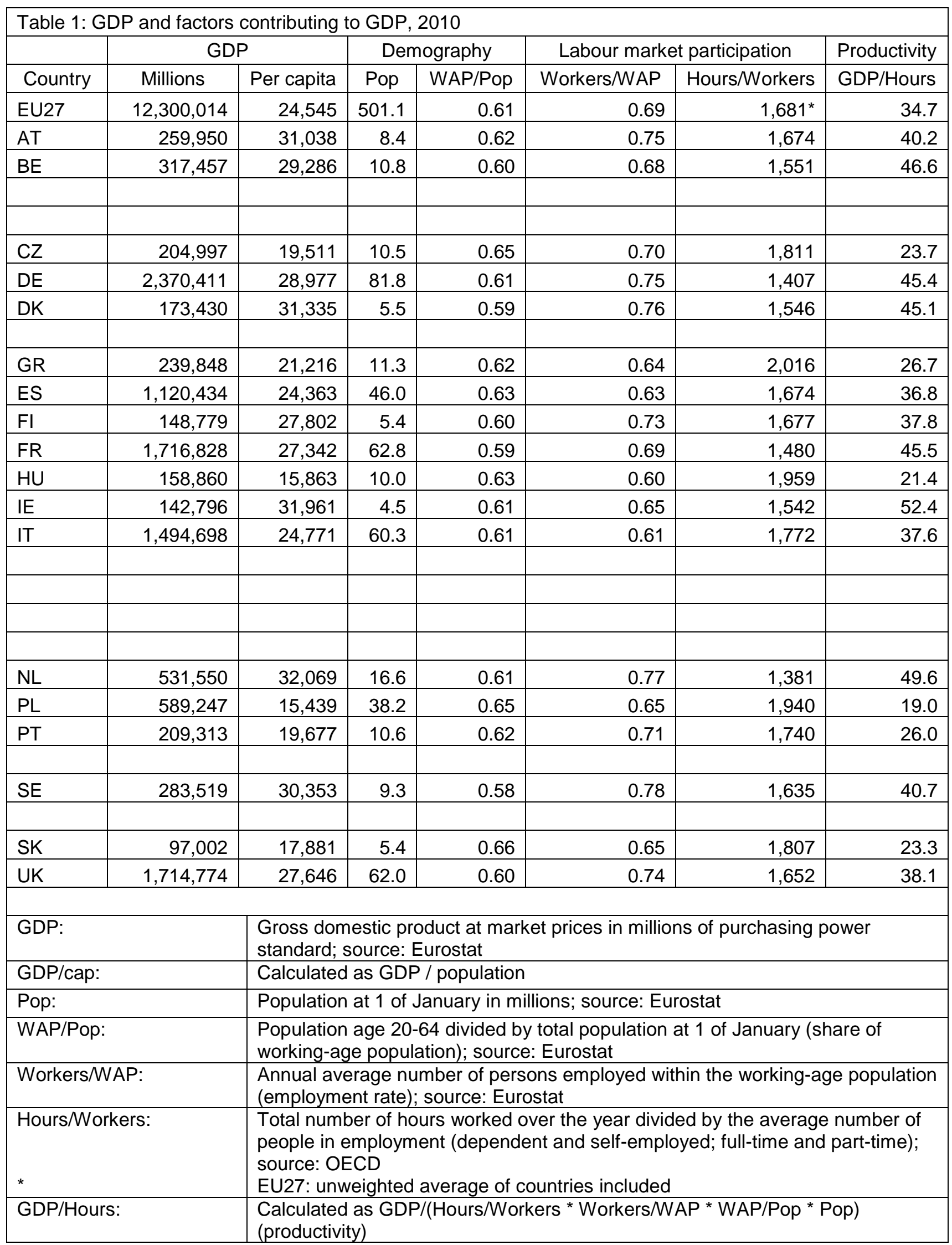

Data: Eurostat / OECD; calculations: NIDI 


\begin{tabular}{|l|r|r|r|r|r|}
\hline \multicolumn{6}{|l|}{$\begin{array}{l}\text { Table 2: Percentage of working-age population employed } \\
\text { (Employment rates*100) }\end{array}$} \\
\hline Country & 2000 & 2008 & 2010 & 2012 & $\begin{array}{r}\text { Europe2020 } \\
\text { target }\end{array}$ \\
\hline EU27 & 66.6 & 70.3 & 68.6 & 68.5 & 75.0 \\
\hline AT & 71.4 & 75.1 & 74.9 & 75.6 & 78.0 \\
\hline BE & 65.8 & 68.0 & 67.6 & 67.2 & 73.2 \\
\hline BG & 55.3 & 70.7 & 65.4 & 63.0 & 76.0 \\
\hline CY & 72.3 & 76.5 & 75.4 & 70.2 & 77.0 \\
\hline CZ & 71.0 & 72.4 & 70.4 & 70.9 & 75.0 \\
\hline DE & 68.8 & 74.0 & 74.9 & 76.7 & 77.0 \\
\hline DK & 78.0 & 79.7 & 75.8 & 75.4 & 80.0 \\
\hline EE & 67.4 & 77.0 & 66.7 & 72.1 & 76.0 \\
\hline ES & 60.7 & 68.3 & 62.5 & 59.3 & 74.0 \\
\hline FI & 71.6 & 75.8 & 73.0 & 74.0 & 78.0 \\
\hline FR & 67.8 & 70.4 & 69.2 & 69.3 & 75.0 \\
\hline GR & 61.9 & 66.5 & 64.0 & 55.3 & 70.0 \\
\hline HU & 61.2 & 61.9 & 60.4 & 62.1 & 75.0 \\
\hline IE & 70.4 & 72.3 & 65.0 & 63.7 & 71.0 \\
\hline IT & 57.4 & 63.0 & 61.1 & 61.0 & 69.0 \\
\hline LT & 65.6 & 72.0 & 64.4 & 68.7 & 72.8 \\
\hline LU & 67.4 & 68.8 & 70.7 & 71.4 & 73.0 \\
\hline LV & 63.5 & 75.8 & 65.0 & 68.2 & 73.0 \\
\hline MT & 57.2 & 59.1 & 60.1 & 63.1 & 62.9 \\
\hline NL & 74.3 & 78.9 & 76.8 & 77.2 & 80.0 \\
\hline PL & 61.0 & 65.0 & 64.6 & 64.7 & 71.0 \\
\hline PT & 73.5 & 73.1 & 70.5 & 66.5 & 75.0 \\
\hline RO & 69.1 & 64.4 & 63.3 & 63.8 & 70.0 \\
\hline SE & 77.7 & 80.4 & 78.7 & 79.4 & $82.0^{*}$ \\
\hline SI & 68.5 & 73.0 & 70.3 & 68.3 & 75.0 \\
\hline SK & 63.5 & 68.8 & 64.6 & 65.1 & 72.0 \\
\hline UK & 74.0 & 75.2 & 73.6 & 74.2 & $75.0^{*}$ \\
\hline Data: & & & & & \\
\hline
\end{tabular}

Data: Eurostat

* For Sweden and the United Kingdom, employment targets are set by the authors to 82 and 75 , respectively 


\begin{tabular}{|c|c|c|c|}
\hline & $\begin{array}{l}\text { Population } \\
\text { growth }\end{array}$ & $\begin{array}{l}\text { Growth } \\
\text { WAP }\end{array}$ & $\begin{array}{l}\text { Demographic } \\
\text { burden }\end{array}$ \\
\hline & 2010-20 & $2010-20$ & 2010-20 \\
\hline \multicolumn{4}{|l|}{ Urban NUTS 2 regions } \\
\hline EUROPOP2008 ${ }^{1}$ & 0.44 & 0.14 & -0.29 \\
\hline High population growth and divergence ${ }^{2}$ & 0.54 & 0.25 & -0.29 \\
\hline $\begin{array}{l}\text { Low population growth and } \\
\text { convergence }\end{array}$ & 0.29 & 0.02 & -0.27 \\
\hline Ageing $^{3}$ & 0.19 & -0.17 & -0.36 \\
\hline Urbanization $^{3}$ & 0.38 & 0.16 & -0.22 \\
\hline \multicolumn{4}{|l|}{ Rural NUTS 2 regions } \\
\hline EUROPOP2008 ${ }^{1}$ & -0.03 & -0.35 & -0.32 \\
\hline High population growth and divergence ${ }^{2}$ & -0.29 & -0.66 & -0.37 \\
\hline $\begin{array}{l}\text { Low population growth and } \\
\text { convergence }^{2}\end{array}$ & -0.36 & -0.67 & -0.31 \\
\hline Ageing $^{3}$ & -0.15 & -0.47 & -0.32 \\
\hline Urbanization $^{3}$ & -0.29 & -0.50 & -0.22 \\
\hline
\end{tabular}

